University of Nebraska - Lincoln

DigitalCommons@University of Nebraska - Lincoln

Biological Systems Engineering: Papers and

Publications

Biological Systems Engineering

2016

\title{
In-field fuel use and load states of agricultural field machinery
}

\author{
Santosh Pitla \\ University of Nebraska-Lincoln, spitla2@unl.edu \\ Joe D. Luck \\ University of Nebraska-Lincoln, jluck2@unl.edu \\ Jared Werner \\ University of Nebraska-Lincoln \\ Nannan Lin \\ Ohio State University \\ Scott A. Shearer \\ Ohio State University, shearer.95@osu.edu
}

Follow this and additional works at: https://digitalcommons.unl.edu/biosysengfacpub

Part of the Applied Mechanics Commons, Bioresource and Agricultural Engineering Commons, Computational Engineering Commons, Computer and Systems Architecture Commons, Data Storage Systems Commons, Environmental Engineering Commons, Other Civil and Environmental Engineering Commons, Other Computer Engineering Commons, and the Other Mechanical Engineering Commons

Pitla, Santosh; Luck, Joe D.; Werner, Jared; Lin, Nannan; and Shearer, Scott A., "In-field fuel use and load states of agricultural field machinery" (2016). Biological Systems Engineering: Papers and Publications. 469.

https://digitalcommons.unl.edu/biosysengfacpub/469

This Article is brought to you for free and open access by the Biological Systems Engineering at DigitalCommons@University of Nebraska - Lincoln. It has been accepted for inclusion in Biological Systems Engineering: Papers and Publications by an authorized administrator of DigitalCommons@University of Nebraska Lincoln. 


\title{
In-field fuel use and load states of agricultural field machinery
}

\author{
Santosh K. Pitla, ${ }^{1}$ Joe D. Luck, ${ }^{1}$ Jared Werner, ${ }^{1}$ Nannan Lin, ${ }^{2}$ Scott A. Shearer ${ }^{2}$ \\ 1 Department of Biological Systems Engineering, University of Nebraska-Lincoln, Lincoln, NE, USA \\ 2 Department of Food Agricultural and Biological Engineering, Ohio State University, Columbus, OH, USA \\ Corresponding author - S. Pitla, 207 L.W. Chase Hall, Department of Biological Systems Engineering, University of Nebraska-Lincoln, \\ Lincoln, NE, USA. Tel.: +1 402472 1466. E-mail address: spitla2@unl.edu (S.K. Pitla).
}

\begin{abstract}
The ability to define in-field tractor load states offers the potential to better specify and characterize fuel consumption rate for various field operations. For the same field operation, the tractor experiences diverse load demands and corresponding fuel use rates as it maneuvers through straight passes, turns, suspended operation for adjustments, repair and maintenance, and biomass or other material transfer operations. It is challenging to determine the actual fuel rate and load states of agricultural machinery using force prediction models, and hence, some form of in-field data acquisition capability is required. Controller Area Networks (CAN) available on the current model tractors provide engine performance data which can be used to determine tractor load states in field conditions. In this study, CAN message data containing fuel rate, engine speed and percent torque were logged from the tractor's diagnostic port during anhydrous $\mathrm{NH} 3$ application, field cultivation and planting operations. Time series and frequency plots of fuel rate and percent torque were generated to evaluate tractor load states. Based on the percent torque, engine speed and rated engine power, actual load on the tractor was calculated in each tractor load state. Anhydrous NH3 application and field cultivation were characterized by three distinct tractor load states (TS-I, TS-II and TS-III) corresponding to idle states, parallel and headland passes, and turns, whereas corn planting was characterized by two load states (TS-I and TS-II): idle, and a combined state with parallel, headland passes and turns. For anhydrous $\mathrm{NH} 3$ application and field cultivation at ground speeds of $7.64 \mathrm{~km} \mathrm{~h}^{-1}$ and $8.68 \mathrm{~km} \mathrm{~h}^{-1}$, average tractor load per tool and fuel use rate per tool of the implement were found to be $7.21 \mathrm{~kW} \mathrm{tool}^{-1}, 3.28 \mathrm{~L} \mathrm{~h}^{-1}$ tool $^{-1}$, and $1.31 \mathrm{~kW} \mathrm{tool}^{-1}, 0.64 \mathrm{~L} \mathrm{~h}^{-1}$ tool $^{-1}$, respectively. For planting, average tractor load per row and fuel use rate per row were found to be $4.65 \mathrm{~kW} \mathrm{row}^{-1}$ and $1.70 \mathrm{~L} \mathrm{~h}^{-1} \mathrm{row}^{-1}$ at a ground speed of $7.04 \mathrm{~km} \mathrm{~h}^{-1}$.
\end{abstract}

Keywords: Controller, CAN, Tractor, Machinery, Load, Performance

\section{Introduction}

Tractors are used for multiple field operations during the entire working season and hence are subjected to varying load demands. Further, for a specific operation, the load demands on the tractor change as a result of ground speed variations, effective implement working widths and depth of operations, field conditions (e.g., soil variability and terrain slope), and machine handling by the operator. When selecting and matching equipment complements, data is readily available for projecting engine load demands of various field operations (ASABE, 2011a). The reference data provides required draft forces at typical working speeds for specific operations (chisel plowing, seeding, etc.), however these power requirements (draft and rotary) of the implements vary within a maximum range of $\pm 50 \%$ based on the type of operation (ASABE, 2011a). A more accurate estimation of power drawn by the implements during different tractor loading states such as working periods (e.g., parallel and headland passes) and non-working periods (e.g. field adjustments and repairs) is required. Understanding actual load profiles of the tractor in different working states has the potential to yield true average load conditions. Improved fuel consumption estimation, and better tractor and implement matching are some of the benefits of in-field tractor load state determination.

Tractor performance is currently evaluated using OECD 2 test code $(O E C D, 2012)$ where tractors are operated under steady-state conditions, selected engine speeds and torques which are a subset of several field operating conditions. Power take-off (PTO) power, drawbar power, and specific fuel consumption are reported to assess the performance of a tractor under controlled conditions. However, measuring the performance of the tractor under field conditions is central to a more thorough understanding of the actual power consumed by implements for various working phases of field operations. 
Engine speed and load also effect emissions, and hence, accurate load estimation of the tractor will indirectly lead to improved emission calculations and fuel consumption measurements. Thus, determination of in-field tractor load states is essential for improved fuel efficiency, better matching of implements to tractors, and accurate estimation of emissions.

Tractor load state estimation and performance testing has been the subject of many engine development and emission control investigations. More recently, manufacturers have focused their attention on off-highway engine emissions. Specifically, ISO 8178 (ISO, 2006) suggests engine test cycles (e.g. type C1, C2, and D1) for various classes of engines and equipment. These cycles include a sequence of steady-state modes for evaluating engine emission performance. Unfortunately, the test cycle conditions deviate from engine operating conditions experienced in actual field applications. ASABE (2011b) provides practices to follow when estimating fuel use rate and draft power requirements for hitched and other types of equipment loads. However, recommendations are not made for fuel consumption during non-working periods including when the tractor is stopped for field adjustment or repair and maintenance, when the tractor is making end-of-row turns, or when the tractor is operated at reduced speeds to accomplish field border passes.

Efforts are underway to predict off-road equipment emissions. An emission inventory model known as NONROAD was developed to predict emissions based on the equipment use (Harvey, 2003). The model estimates an emission factor which is a function of transient adjustment factors (TAFs). The TAFs are based on engine speeds and loads (both transient and steady-state) of off-road equipment. A load factor of 0.78 was considered for agricultural tractors in predicting the emission factors (Harvey, 2003). This load factor is an approximate indicator of the true load factors of the agricultural machinery, and depending on the type of operation, could have either overestimated or underestimated the engine load factor.

In-field machine performance data acquisition could be of significant value for determining actual load factors and states of tractors. Burgun et al. (2013) conducted a long term data acquisition campaign for evaluating mechanical energy needs of the plowing operation, and suggested dual alternating profile of loads. Further they used steady-state bench test results to predict operational efficiency and field load conditions. Two indicators, time efficiency (h $\left.\mathrm{ha}^{-1}\right)$ and area specific fuel consumption $\left(\mathrm{L} \mathrm{ha}^{-1}\right)$ made these predictions possible. Yahya et al. (2009) developed a data acquisition system for use with an agricultural tractor for mapping tractor-implement performance while disk plowing a field. In a similar effort, Al-Suhaibani et al. (2010) instrumented a tractor for measuring performance parameters and the draft forces of various implements at different depths and speeds. The authors found good correlations between measured and predicted values of draft force, which validated the instrumentation methodology. The availability of the Controller Area Network (CAN) bus on the tractors is allowing researchers to obtain tractor performance data (Lin, 2014; Pitla et al., 2013; Darr, 2012). Pitla et al. (2014) obtained tractor fuel use rate messages from the CAN bus to determine field efficiencies of row crop operations based on a threshold fuel use rate methodology. Further, researchers have compared CAN bus fuel use rates of tractors to physical tractor fuel measurements to understand the accuracy of CAN fuel rate data (Cupera and Sedlak, 2011; Marx, 2015; Marx et al., 2015). The study conducted by Marx et al. (2015) concluded that a maximum error of $6.22 \%$ between the physical fuel rate measurement and the CAN bus fuel rate measurement is possible. Fuel rate errors were found to be higher at lower fuel rates, whereas for higher engine fuel use rates within the torque curve the errors were found to be closer to $\pm 1 \%$ (Marx et al., 2015). Thus, given the utility and availability of CAN bus data on current day machinery, this source of data provides an attractive alternative for tractor performance evaluation. As part of this research, CAN bus data were recorded for estimating true load states of the tractors performing typical row crop production operations.

\section{Objectives}

The specific objectives of this investigation were to:

(1) Obtain CAN messages related to tractor performance from the communication diagnostic ports of four wheel drive (4WD) and mechanical front wheel drive (MFWD) tractors during row crop production field operations (e.g., anhydrous ammonia $\left(\mathrm{NH}_{3}\right)$ application, field cultivation and planting).

(2) Determine actual fuel use rates and power consumption in different load states of the tractors performing $\mathrm{NH}_{3}$ application, cultivation and planting.

\section{Materials and methods}

CAN bus data were logged from a $245 \mathrm{~kW}$ rated 4WD tractor (JD 9410R, Deere \& Co., Moline, IL) and a $127 \mathrm{~kW}$ rated MFWD tractor (JD 7200R, Deere \& Co., Moline, IL) during field operations. The 4WD tractor (see Figure 1a) was used to pull an $\mathrm{NH}_{3}$ applicator (DW 6032, Dalton Ag Products, Lenox, IA) and a field cultivator (JD 2210, Deere \& Co., Moline, IL) shown in Figure 1b.The MFWD tractor (see Figure 1c) was used for planting corn with a 16 row central-fill planter (JD 1770 NT, Deere \& Co., Moline, IL).

CAN data were logged with a Vector ${ }^{\mathrm{TM}}$ CAN data logger (CANcase XL log, Vector, Stuttgart, Germany) and CANalyzer software installed on a laptop computer (see Figure 2). Data were logged from both the implement and tractor channels of the CAN bus. Tractor data from a total of six unique fields were collected. Machinery used for the study, field names, specifications of the implements, and the CAN data bus loads (\%) of the tractors are summarized in Table 1. CAN messages logs were imported into Excel for sorting and extraction of machine operating parameters. A screenshot of the CANalyzer interface with CAN messages can be seen in Figure 3. While all messages were logged, only the SAE J1939 messages were considered for the study as the identifiers and data formats were readily available through the SAE J1939 database (SAE, 2013). The primary messages used in this investigation were the Electronic Engine Controller 1 (EEC1 - CF00400 hex $_{-}$PGN 61444) and Liquid Fuel Economy (LFE - 18FEF200 hex $_{-}$PGN 65266), both highlighted in Figure 3. Data relevant to this investigation included in the EEC1 message were actual engine torque in percent, and engine speed in rpm. The LFE message provided the engine fuel use rate in $\mathrm{L} \mathrm{h}^{-1}$. From Figure 3 , it can be observed that the data in the CAN messages were in hexadecimal format. Contents of the EEC1 and LFE message frame in hexadecimal format and their respective message identifiers is presented in Figure 4. The hexadecimal data in the messages were converted to engineering units based on the conversion factors and procedures available in the SAE J1939 database (SAE J1939, 2013). The LFE message provided the engine fuel use rate in $L \mathrm{~h}^{-1}$ with a resolution of $0.05 \mathrm{~L} \mathrm{~h}^{-1}$ bit $^{-1}$, whereas EEC1 message provided actual percent engine torque with a resolution of $1.0 \% \mathrm{bit}^{-1}$, and engine speed in rpm with a resolution of $0.125 \mathrm{rpm} \mathrm{bit}^{-1}$. As an example, to convert the hexadecimal data of the LFE message, D0 and D1 data bytes of the LFE message (see Figure 4a) which corresponded to the fuel use rate were converted into decimal numbers and combined to yield bits. These combined bits of D0 and D1 (1123) were multiplied by $0.05 \mathrm{~L} \mathrm{~h}^{-1}$ bit $^{-1}$ conversion factor to obtain fuel use rate in $\mathrm{L} \mathrm{h}^{-1}$. D0 and D1 data byte values of the LFE message shown in Figure $4 a$, yielded a fuel use rate of $56.15 \mathrm{~L} \mathrm{~h}^{-1}$. Similar procedure was followed to decode data bytes D2, D3 and D4 of the EEC1 message 


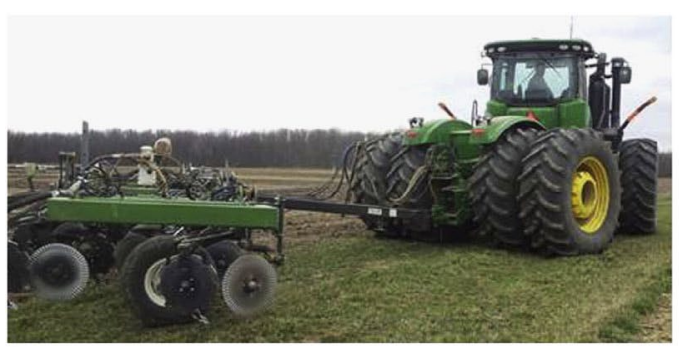

(a) 4WD tractor pulling the anhydrous applicator

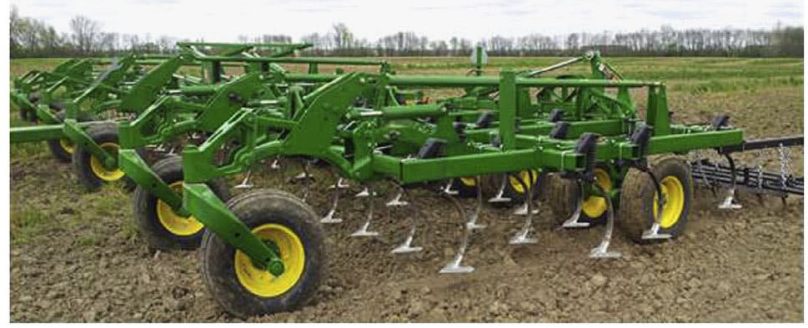

(b) Field cultivator pulled by the $4 \mathrm{WD}$ tractor

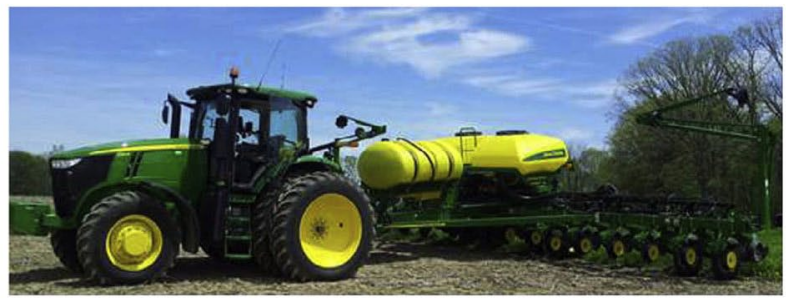

(c) MFWD tractor pulling the corn planter

Figure 1. (a) 4WD tractor pulling the anhydrous applicator, (b) field cultivator pulled by the 4WD tractor and (c) MFWD tractor pulling the corn planter.

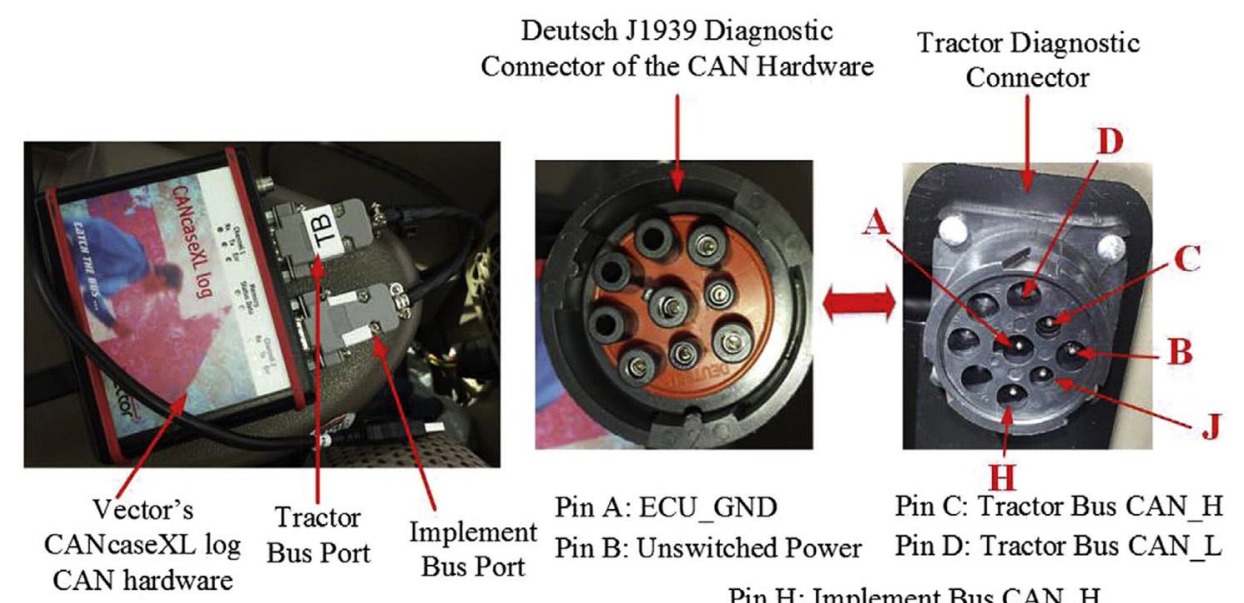

Pin H: Implement Bus CAN_H

Pin J: Implement Bus CAN_L

Figure 2. CAN bus hardware used for CAN data collection from tractor and implement bus.

Table 1. Summary of the equipment used, field names, and the CAN bus loads of the tractors.

\begin{tabular}{|c|c|c|c|c|c|c|c|}
\hline \multirow[t]{2}{*}{ Implement } & \multirow[t]{2}{*}{ Field name } & \multirow{2}{*}{$\begin{array}{l}\text { Implement } \\
\text { width (m) }\end{array}$} & \multirow[t]{2}{*}{ Tractor used } & \multicolumn{2}{|c|}{ Channel I (tractor bus) } & \multicolumn{2}{|c|}{ Channel II (implement bus) } \\
\hline & & & & Baud rate (kbps) & Bus load (\%) & Baud rate (kbps) & Bus load (\%) \\
\hline Anhydrous applicator & $3 M S I D$ & 10 & $4 W D$ & 500 & 32.7 & 250 & 18.8 \\
\hline Field cultivator & $1 C$ & 13.7 & $4 \mathrm{WD}$ & 500 & 32.3 & 250 & 19.2 \\
\hline Field cultivator & $2 \mathrm{D}$ & 13.7 & $4 W D$ & 500 & 32.4 & 250 & 19.2 \\
\hline Field cultivator & $2 \mathrm{C}$ & 13.7 & $4 W D$ & 500 & 32.3 & 250 & 19.2 \\
\hline Central fill planter & $12 \mathrm{D}$ & 12.2 & MFWD & 500 & 35.4 & 250 & 23.6 \\
\hline
\end{tabular}

which yielded a percent torque of $49 \%$ and an engine speed of $1781.25 \mathrm{rpm}$ (see Figure 4b). It was required to apply an offset of ${ }^{-1} 25 \%$ to the converted percent torque data as a last step to obtain correct percent torque values. For example, the percent torque data byte D2 of the EEC1 message (see Figure $4 b$ ) when converted into percent torque with a conversion factor of $1.0 \%$ bit $^{-1}$ yielded a percent torque value of $174 \%$. An offset of $-125 \%$ was applied to yield the correct percent torque of $49 \%$. Based on the time stamps of the messages, it was observed that LFE messages were generated at a rate of $10 \mathrm{~Hz}$ while EEC1 messages were generated at a rate of 100 


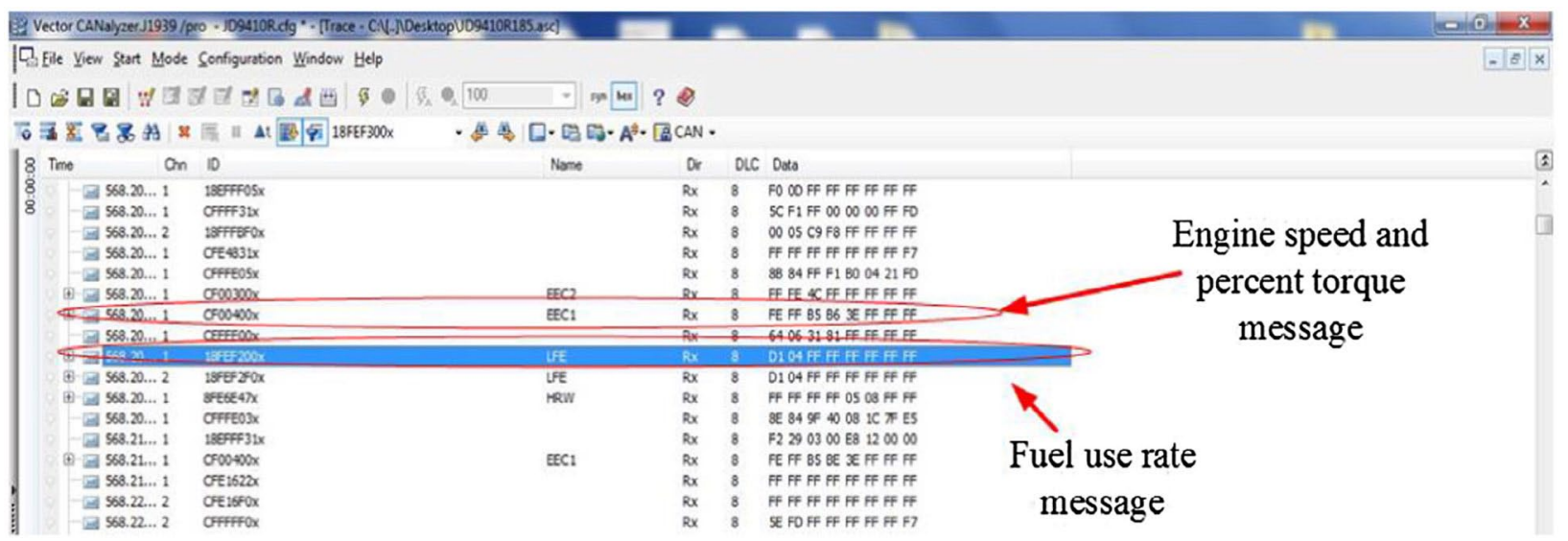

Figure 3. Screenshot of the CAN messages captured using the Vector CANalyzer software.

$\mathrm{Hz}$. Fuel use rate, engine speed and \% torque messages were subsampled and registered to create a data file with a time base of 10 $\mathrm{Hz}$ for the duration of each field operation. In addition to CAN data, National Marine Electronics Association (NMEA) global positioning (GPS) data was obtained from Trimble's FMX display (Trimble Navigation, Ltd., Sunnyvale, California) installed in the tractors. Trimble's Autopilot ${ }^{\mathrm{TM}}$ (Trimble Navigation, Ltd., Sunnyvale, California) was used for automated guidance during field operations which provided Real Time Kinetic (RTK) GPS. Ground speed, latitude and longitude information obtained from Trimble hardware was combined with CAN message data for tractor path analysis.

\section{Results and discussion}

The fuel rate profile for $\mathrm{NH}_{3}$ application presented in Figure 5 illustrates the periods of high and low fuel consumption rates. The peaks corresponded to the parallel and headland passes when the implement was engaged in the soil, whereas the valleys represented end-of-row tractor turns. High fuel rate regions were separated by low fuel rate regions in a sequence which correlated to parallel and headland passes, and end-of-row turns. In addition to the peaks and valleys, between times $3500 \mathrm{~s}$ and $3700 \mathrm{~s}$ there was a period of time when the fuel rate dropped to less than $10 \mathrm{~L} \mathrm{~h}^{-1}$. This

\begin{tabular}{ccc|c|c|c|c|c|c|c|}
$\begin{array}{c}\text { Liquid Fuel } \\
\begin{array}{c}\text { Economy message } \\
\text { (LFE) }\end{array}\end{array}$ & $\begin{array}{c}\text { Message Identifier } \\
\text { 18FEF200x }\end{array}$ & D0 & D1 & D2 & D3 & D4 & D5 & D6 & D7 \\
\hline
\end{tabular}

Decoded fuel use rate $\left(\mathrm{Lh}^{-1}\right) 56.15 \mathrm{Lh}^{-1}$

$\begin{array}{lc}\text { Electronic Engine } & \text { Message Identifier } \\ \text { Controller(EEC1) } & \text { CF00400x }\end{array}$

\begin{tabular}{|c|c|c|c|c|c|c|c|}
\hline D0 & D1 & D2 & D3 & D4 & D5 & D6 & D7 \\
\hline$F E$ & FF & $\mathbf{A E}$ & $\mathbf{A A}$ & 37 & FF & FF & FF \\
\hline
\end{tabular}

Decoded percent torque (\%) $49 \% \quad 1781.25$ RPM Decoded Engine Speed (RPM)

Figure 4. (a) Decoded Liquid Fuel Economy (LFE) message data and (b) Decoded Electronic Engine Controller (EEC1) message data.

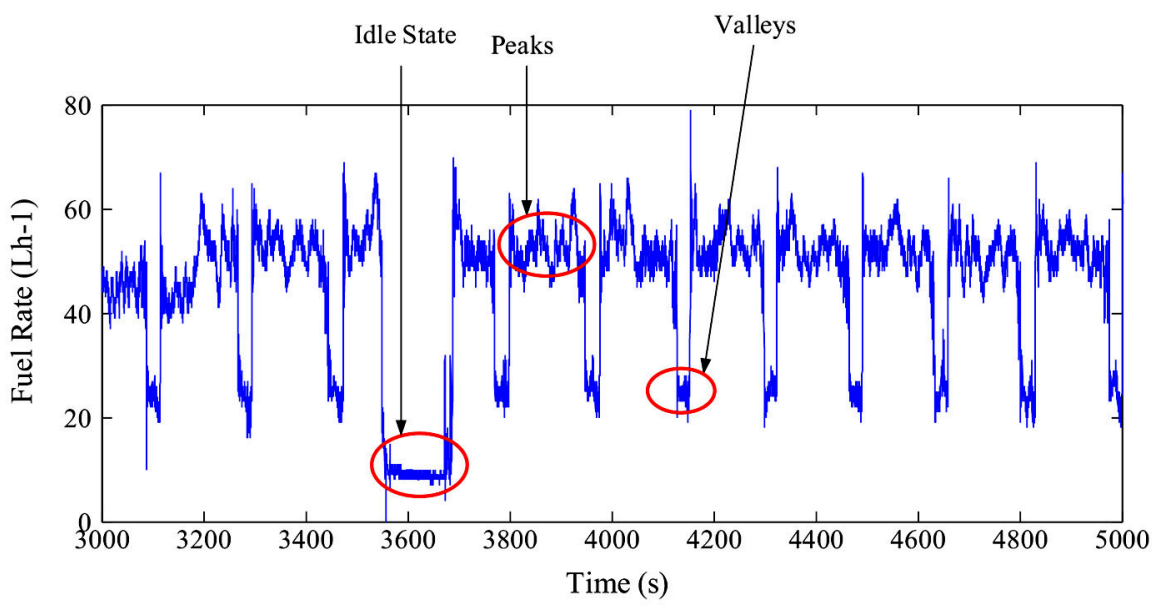

Figure 5. Fuel rate profile of the tractor for NH3 application in Field 3MSID. 
corresponded to the idling of the tractor indicating that the application was stopped by the operator while waiting to exchange $\mathrm{NH}_{3}$ tanks. Thus, fuel rate profile revealed the working and idle states during field operations. It was observed that the valleys and peaks of the CAN fuel rate profile correlated well with the tractor working states in turns and straight passes, respectively (see Figure 6). The corresponding fuel rate frequency distribution of the tractor is shown in Figure 7. There were three distinct distribution regions within this frequency plot. The first tractor state (TS-I) was an idle state where the tractor did not perform any useful work. The tractor experienced low fuel rates (approx. less than $10 \mathrm{~L} \mathrm{~h}^{-1}$ ) during TS-I as the engine was lightly loaded. The second tractor state (TS-II) corresponded to the end-of-row turns, whereas the third state (TS-III) represented parallel and headland passes of the tractor where the $\mathrm{NH}_{3}$ applicator was engaged with the soil. Differentiation between the tractor states was performed graphically followed by confirmation with the threshold fuel rates of implements. Threshold fuel rates correspond to the fuel use rate of the tractor when the implement is engaged in the soil and is a function of the draft force, implement width and the speed of operation (Pitla et al., 2014). TS-III of the $\mathrm{NH}_{3}$ applicator covered significant portion of the frequency distribution indicating that the applicator was in a working state for a significant portion of the field operation. Further, fuel use rate values corresponding to TS-III were higher compared to other states (TS-I and TS-II) indicating that the tractor was loaded heavily when contrasted with the other two states (see Figure 7). In addition to fuel use rate, percent torque is another good indicator of engine load and hence the percent engine torque frequency distribution was plotted (see Figure 8). The percent torque distribution profile trends similar to the fuel use rate distribution as anticipated exhibiting three distinct regions corresponding to idle state (TS-I), end-ofrow turns (TS-II), and working state in parallel and headland passes (TS-III) for the $\mathrm{NH}_{3}$ applicator.

Fuel use rate was plotted against the power $(\mathrm{kW})$ to confirm the validity of the CAN bus data (see Figure 9). A coefficient of determination of 0.96 was obtained indicating a good fit between the power requirements of the drawn implement and the tractor fuel use rate. Weighted averages of the fuel use rate, percent torque and engine speed were calculated based on their occurrences for each of the three states in accordance with Eq. (1)

$X_{\text {wavg }}=\frac{\sum_{i=1}^{n} x_{i} f_{i}}{\sum_{i=1}^{n} f_{i}}$

where

$X_{\text {wavg }}$ is the weighted average of the parameter under consider-

ation: fuel use rate, percent torque and engine speed.

$i \quad$ is the index of the data point.

$n \quad$ is the number of data points in each tractor state.
$x_{i} \quad$ is the current data point.
$f_{i} \quad$ is the frequency of the current data point.

As an example, to obtain weighted average fuel use rate in idle state (TS-I), the frequency of fuel use rate value was multiplied by the corresponding fuel use rate and a summation was performed for the distribution falling within TS-I. The resultant value was divided by the sum of frequencies in the TS-I (idle state) to yield a weighted average value of $6.28 \mathrm{~L} \mathrm{~h}^{-1}$ (see Figure 10). A similar procedure was followed to obtain weighted averages of percent torque and engine speed (rpm). The percentage of field time the machine operated in each tractor state was calculated based on the duration of each state relative to the overall field time (all three states combined). Percent weighted torque, weighted fuel use rate, total fuel consumption and the percent of time expended by the tractor in each of the states (TS-I, TS-II and TS-III) during $\mathrm{NH}_{3}$ application in field 3MSID are presented in Figure 10.

From Figure 10 it can be seen that for 10 min, which corresponded to $7 \%$ of the total work time, the $\mathrm{NH}_{3}$ applicator was using $8 \%$ of the rated torque, consuming $6.28 \mathrm{~L} \mathrm{~h}^{-1}$ with a total fuel consumption of $1.06 \mathrm{~L}$ during the idle state. Total fuel consumption in liters for each working state of the $\mathrm{NH}_{3}$ applicator was calculated based on the data collection rate of $10 \mathrm{~Hz}$ (data point every $0.1 \mathrm{~s}$ ) and the fuel use rate in $\mathrm{L} \mathrm{h}^{-1}$ at each data point. During TS-II, which lasted for $33 \mathrm{~min}$ ( $24 \%$ of total time), the percent weighted torque was $23 \%$, fuel rate was $20.39 \mathrm{~L} \mathrm{~h}^{-1}$ and the total fuel consumption was 10.73 L. For TS-III, which corresponded to parallel and headland passes, the $\mathrm{NH}_{3}$ applicator used $52 \%$ of rated torque at a fuel rate of $52.71 \mathrm{~L} \mathrm{~h}^{-1}$. TS-III took $96 \mathrm{~min}$ (69\% of the total working time) and used $91.10 \mathrm{~L}$ of fuel during this state indicating that TS-III was the high energy demand state of the $\mathrm{NH}_{3}$ applicator. Perhaps the best opportunities for energy savings may be realized in this work state as it corresponded to the high energy consumption state of the tractor operation. The procedure discussed above was repeated to obtain weighted percent torque, weighted fuel rate and percent of total field time of each tractor state during field cultivation and planting operations. $\mathrm{NH}_{3}$ application and field cultivation operations were represented by three distinct working states, whereas planting had only two distinct tractor states. For planting operation, working state in parallel and headland passes was not distinguishable from the end-of-row turns. Percent torque and fuel use rate distribution plots for corn planting in field 12D can be seen in Figures 16a and $11 \mathrm{~b}$, respectively.

TS-I is the idle state of the tractor, whereas TS-II corresponded to combined working state in turns, headland and parallel passes. Unlike $\mathrm{NH}_{3}$ application and field cultivation, where only drawbar power of the tractor was used, planting operation used drawbar, PTO and hydraulic power of the tractor, simultaneously. The central fill planter

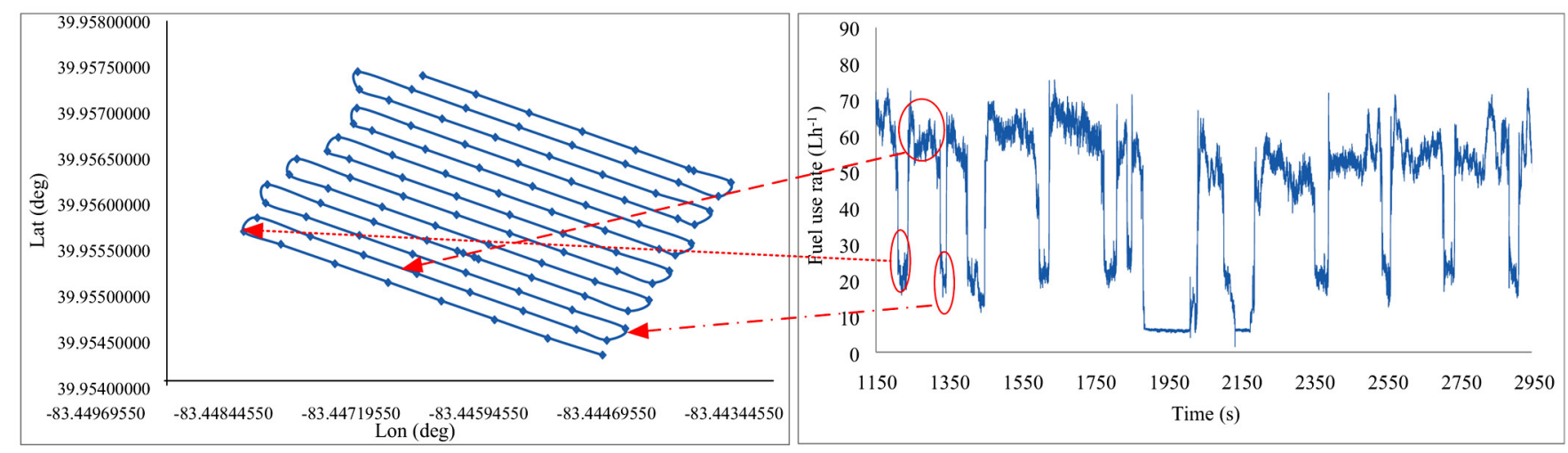

Figure 6. Turns and straight passes compared to the valleys and peaks of fuel rate profile. 


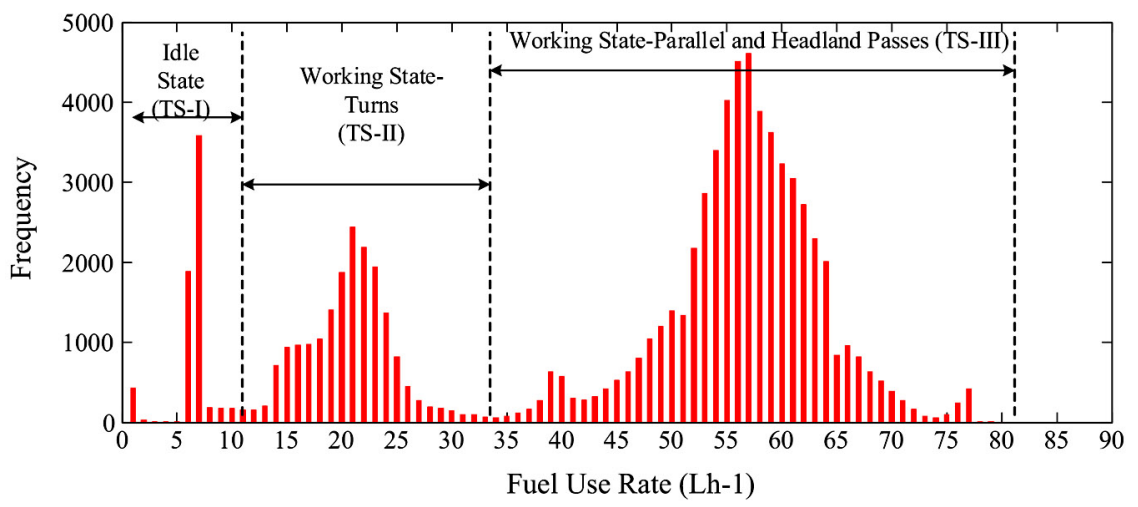

Figure 7. Fuel rate distribution of the tractor for anhydrous NH3 application in Field 3MSID.

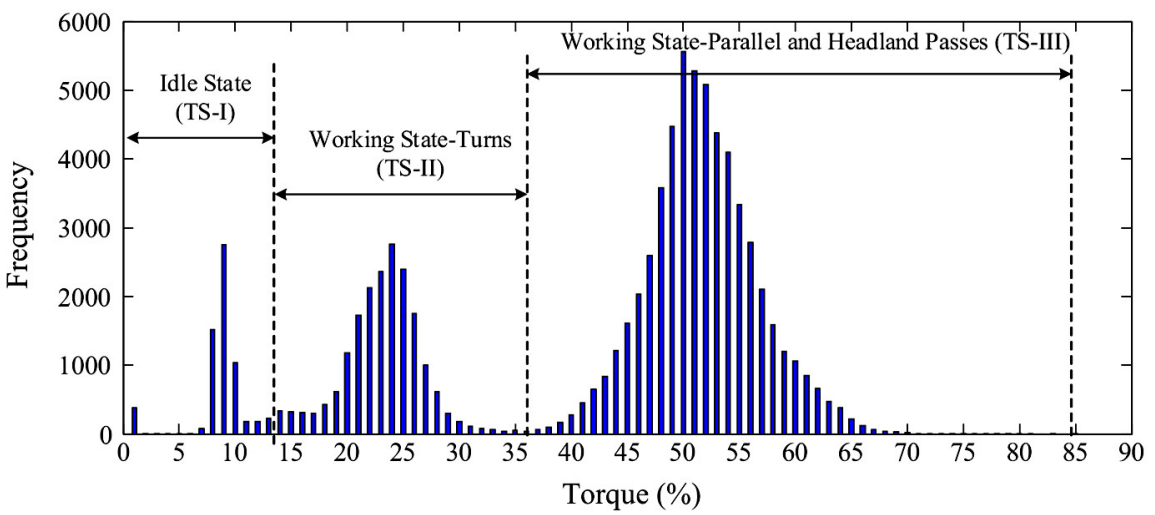

Figure 8. Percent torque distribution for NH3 application in field 3MSID.

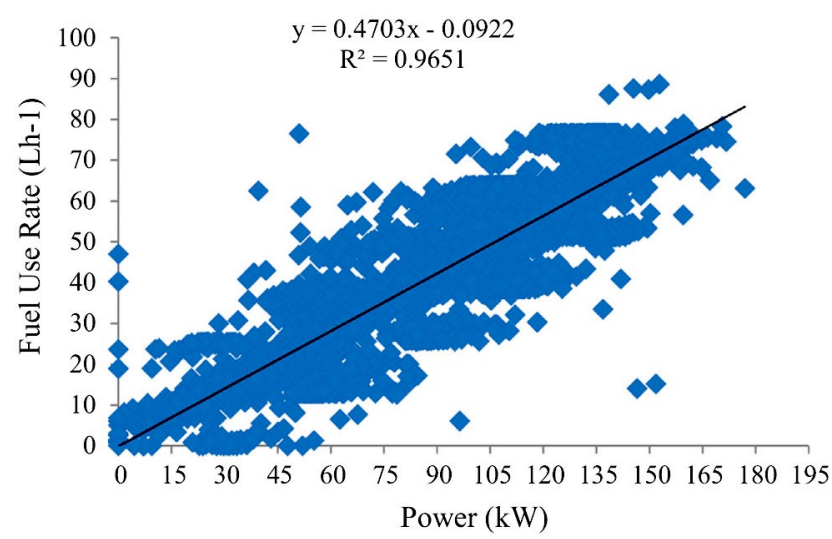

Figure 9. Correlation between fuel use rate and the power $(\mathrm{kW})$ of the 4WD tractor in field 3MSID.

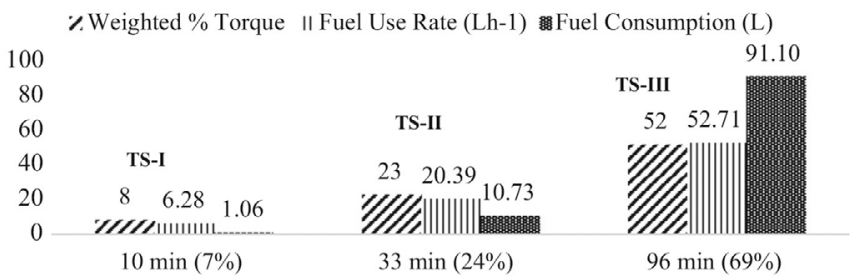

Time duration-minutes ( $\%$ of total time)

Figure 10. Weighted average percent torque, weighted average fuel use rate and fuel consumption of $\mathrm{NH} 3$ application in Field 3MSID for tractor states (TS-I, TS-II and TS-III). used the hydraulic-drive fans to transfer seed from the central tank to the individual row units and to provide airflow at the seed meters for singulation. The planter used power from multiple sources of the tractor there by placing high demand on the engine. Even when the planter was not engaged in the soil the tractor was still under load due to power drawn from the PTO and hydraulic selective control valves. This could be one of the reasons why there was no distinct separation in the percent torque frequency plot between working state in turns (planter row units disengaged) and working state in parallel and headland passes (planter row units engaged).

For planting in field $1 \mathrm{C}$, the tractor was in idle state for a significant portion of time. This was evident from high frequencies of percent torque values between approximately $25 \%$ and $45 \%$ torque values in Figure 12a. The idle state of the tractor is also represented in percent torque profile of the tractor in Figure $12 \mathrm{~b}$.

The highlighted areas in Figure 12b correspond to idle state of the tractor where the percent torque values were low for extended periods of times indicating that the tractor was stopped frequently. Based on the field notes taken it was confirmed that the operator stopped the tractor frequently to check the seed spacing and depth within the furrow. As field $1 \mathrm{C}$ was the first field to be planted, the operator evaluated the quality of seed placement on multiple occasions during which time the tractor stopped while the operator was making adjustments.

Weighted average percent torque, weighted average fuel rate, and percent total field time of the 4WD tractor operating the $\mathrm{NH}_{3}$ applicator and field cultivator in each tractor state (TS-I, TS-II and TS-III) are summarized in Table 2. On an average the 4WD tractor worked approximately $70 \%$ of the field time in TS-III for both $\mathrm{NH}_{3}$ application and field cultivation operations indicating that the tractor was in high load state for majority of the field time (see Table 2). For $\mathrm{NH}_{3}$ application, the weighted average percent torque in TS-III was 


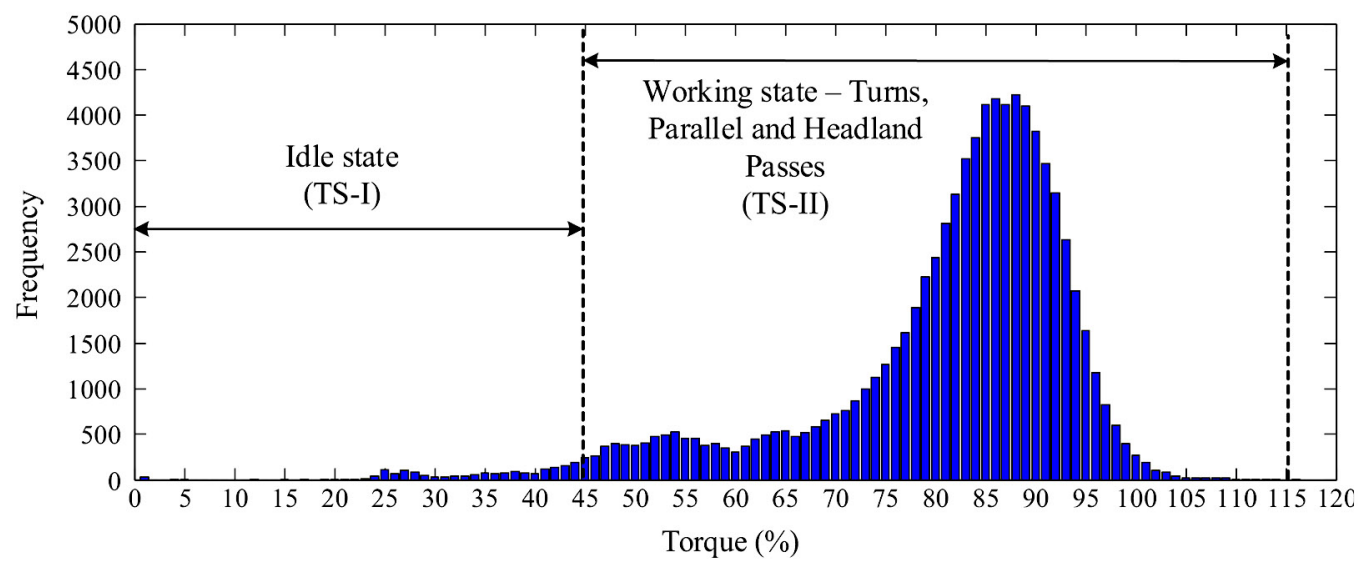

(a)

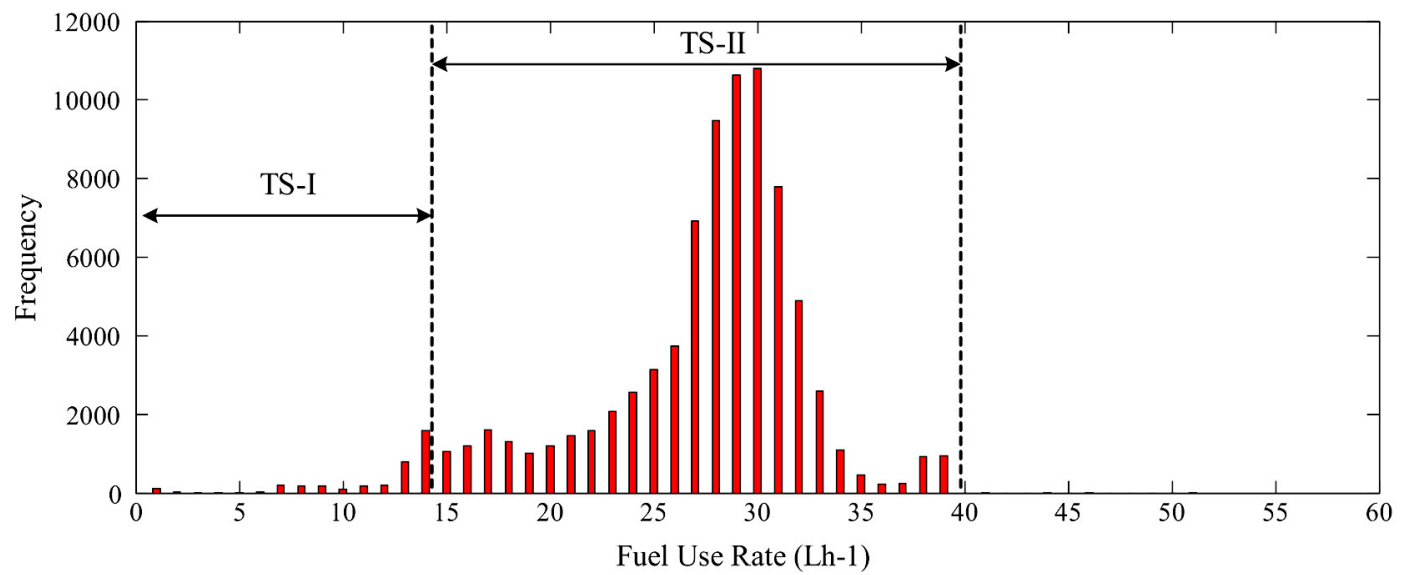

(b)

Figure 11. (a) Percent torque distribution and (b) fuel use rate distribution for planting in field 2D.

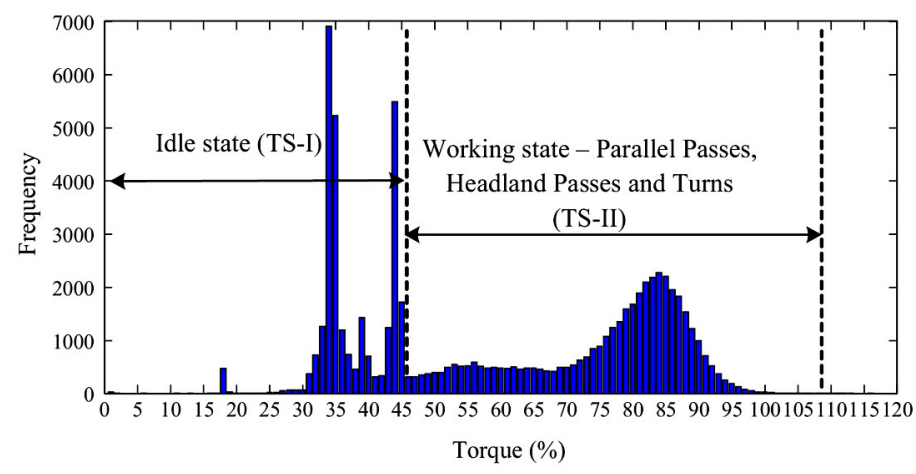

(a)

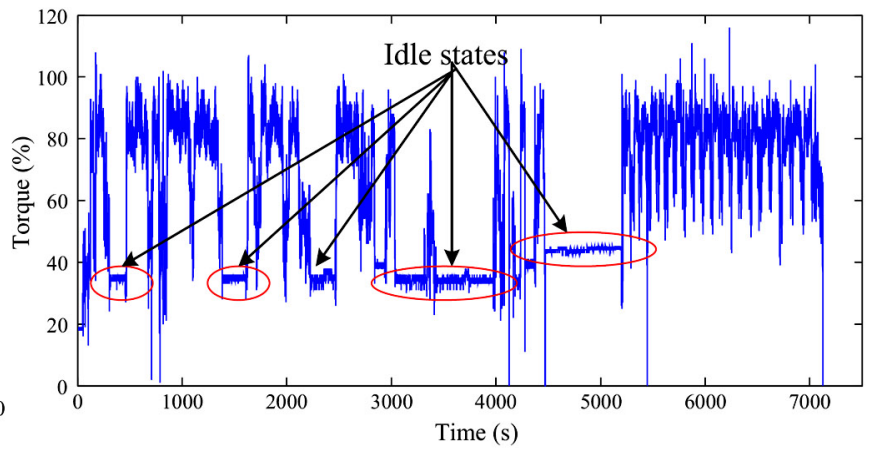

(b)

Figure 12. (a) Percent torque distribution and (b) percent torque profile for planting in field $1 \mathrm{C}$.

Table 2. Weighted average percent torque and weighted average fuel use rate of 4WD tractor during anhydrous NH3 application and field cultivation in TS-I, TS-II and TS-III.

\begin{tabular}{|c|c|c|c|c|c|c|c|c|c|c|c|}
\hline \multirow[t]{2}{*}{ Field operation } & \multirow{2}{*}{$\begin{array}{l}\text { Field } \\
\text { name }\end{array}$} & \multirow{2}{*}{$\begin{array}{l}\text { Avg. ground } \\
\text { speed }\left(\mathrm{km} \mathrm{h}^{-1}\right)\end{array}$} & \multicolumn{3}{|c|}{ Weighted average torque (\%) } & \multicolumn{3}{|c|}{ Weighted average fuel rate $\left(\mathrm{L} \mathrm{h}^{-1}\right)$} & \multicolumn{3}{|c|}{$\%$ of total field time } \\
\hline & & & TS-I & TS-II & TS-III & TS-I & TS-II & TS-III & TS-I & TS-II & TS-III \\
\hline NH3 Application & $3 M S I D$ & 7.45 & 8 & 23 & 52 & 6.28 & 20.39 & 52.71 & 8 & 22 & 70 \\
\hline \multirow[t]{3}{*}{ Field Cultivation } & $1 C$ & 8.08 & 13 & 33 & 66 & 13.20 & 31.69 & 66.57 & 4 & 25 & 71 \\
\hline & $2 \mathrm{C}$ & 9.17 & 13 & 35 & 68 & 11.66 & 33.18 & 74.55 & 3 & 27 & 70 \\
\hline & $2 \mathrm{D}$ & 8.80 & 13 & 33 & 63 & 7.11 & 30.91 & 65.61 & 3 & 24 & 73 \\
\hline
\end{tabular}


approximately double the percent torque values of TS-II whereas, the fuel use rate values in TS-III were approximately two and half times the fuel use rate values occurring in TS-II (see Table 2). For field cultivation, in all the fields, weighted percent torque and the fuel use rate in TS-III were found to be approximately twice that of the weighted torque and fuel use rate values of TS-II. As expected the weighted average percent torque and fuel use rates were relatively low in TS-I states where the tractor was in idle state. These results clearly indicate that the load and fuel demands on the tractor change significantly within the field depending on whether the implement is engaged in the soil or not. For field $2 \mathrm{C}$ during field cultivation, the weighted fuel use rate of $74.55 \mathrm{~L} \mathrm{~h}^{-1}$ in TS-III was much higher than the fuel use rate in field $1 \mathrm{C}$ and field $2 \mathrm{D}$ as the tractor was travelling at a higher ground speed of $9.2 \mathrm{~km} \mathrm{~h}^{-1}$ compared to the ground speeds of 8.1 and $8.8 \mathrm{~km} \mathrm{~h}^{-1}$ in fields $1 C$ and $2 \mathrm{D}$, respectively.

Rated power (4WD: $245 \mathrm{~kW}$ and MFWD: $127 \mathrm{~kW}$ ) and rated engine speeds (4WD and MFWD: $2100 \mathrm{rpm}$ ) obtained from the official Nebraska tractor test reports of the tractor models were used to determine the actual rated torque values of the tractors. The weighted percent torque obtained from CAN data in each state was converted to torque in $\mathrm{N} \mathrm{m}$ based on the rated torque value. Percent weighted torque, as summarized in Table 2, was converted to weighted torque ( $\mathrm{N} \mathrm{m}$ ) (see Table 3) based on the rated power and engine speed of the 4WD tractor. The torque obtained was converted to power $(\mathrm{kW})$ using the weighted engine speed in rpm of each tractor state (see Table 3).

Highest load demand of $155.91 \mathrm{~kW}$ on the tractor was found to be in TS-III of the field cultivation operation in field 2C, whereas the lowest demand of $8.26 \mathrm{~kW}$ on the tractor was found to be in TS-I of the $\mathrm{NH}_{3}$ application in field 3MSID. Weighted average fuel rate and power were weighted averaged across the fields for $\mathrm{NH}_{3}$ application and field cultivation based on the percent time of the tractor states separately to yield overall tractor load states of each field operation. For $\mathrm{NH}_{3}$ application, the weighted average loads across the fields in TS-I, TS-II and TS-III were found to be $9.20 \mathrm{~kW}, 46.96 \mathrm{~kW}$ and 118.10 $\mathrm{kW}$ with tractor operating at an average ground speed of $7.64 \mathrm{~km}$ $\mathrm{h}^{-1}$ (see Figure 13). These load values were divided by the rated engine power of the tractor.

These load values were divided by the rated engine power of the tractor to yield the percent loads of the tractors in each state. The weighted average fuel use rates in each of the three states were found to be $6.38 \mathrm{~L} \mathrm{~h}^{-1}, 21.67 \mathrm{~L} \mathrm{~h}^{-1}$ and $53.36 \mathrm{~L} \mathrm{~h}^{-1}$ (see Figure 13). The load states of $\mathrm{NH}_{3}$ application indicated that high demand of $118.10 \mathrm{~kW}$ occurred for $70 \%$ of the field time, whereas medium load and low load demands of $46.96 \mathrm{~kW}$ and $9.20 \mathrm{~kW}$ occurred for $22 \%$ and $8 \%$ of the field times (see Figure 13). Similar procedure was followed to determine the weighted average fuel use rate and loads of the field cultivation operation across three fields considered in the study. Weighted average power and fuel use rates of the tractor in three states for the field cultivation across the fields are summarized in Figure 14. The 4WD tractor was under higher load during field cultivation relative to $\mathrm{NH}_{3}$ application based on the weighted average

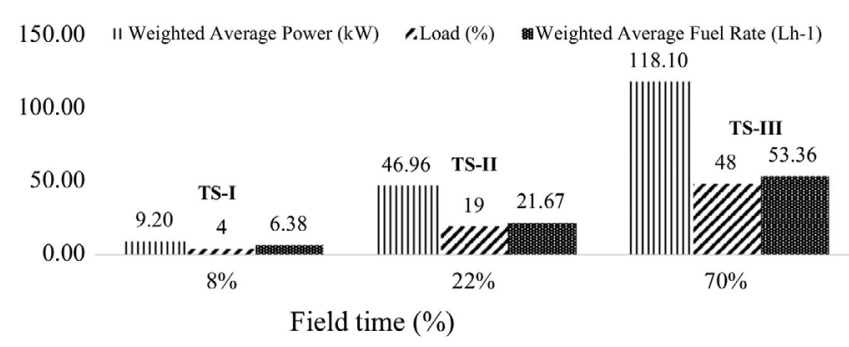

Figure 13. Weighted average power and fuel use rate of the 4WD tractor in TS-I, TS-II and TS-III across the fields (3MSID, 4A) for NH3 application.

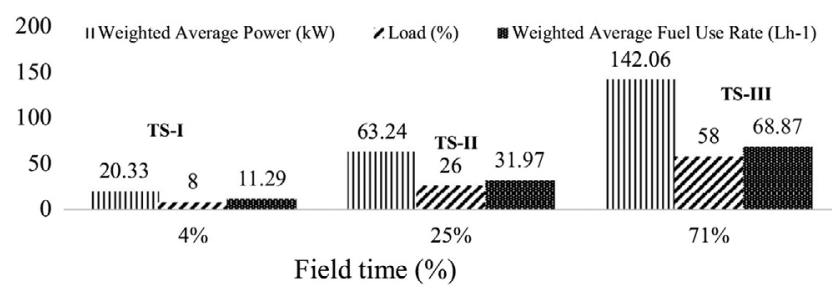

Figure 14. Weighted average power and fuel use rate of the 4 WD tractor in TS-I, TS-II and TS-III across fields (1C, 2C, 2D) for field cultivation.

power and fuel use rates in TS-I, TS-II and TS-III. For $71 \%$ of the field time, the cultivator was exerting a load demand of $142.06 \mathrm{~kW}$ on the tractor in TS-III, $63.24 \mathrm{~kW}$ for $25 \%$ of the field time and $20.33 \mathrm{~kW}$ for $4 \%$ of the time in TS-II and TS-I, respectively. Thus, the actual infield load states of the 4WD tractor while pulling both the $\mathrm{NH}_{3}$ applicator and field cultivator in three tractor states were quantified.

The weighted percent torque and fuel use rate values of the MFWD tractor during planting operation in three fields are summarized in Table 4. Comparing the percent of total field times of tractor states, it is evident that in fields 2D and 12D for $96 \%$ and $98 \%$ of the field time, respectively, the tractors were in TS-II which corresponded to a combined working state of parallel passes, headland passes and turns (see Table 4). However, for field 1C, the tractor spent $41 \%$ of the time in TS-I where the tractor was in an idle state, and the remaining $59 \%$ of the time the tractor was working in parallel passes, headland passes and turns.

As discussed earlier, the tractor was stopped on multiple occasions by the operator in field $1 \mathrm{C}$ to evaluate seed depth and spacing which resulted in multiple idle time periods. The fuel use rate and percent torque in TS-II were more than double compared to the fuel rate and percent torque in TS-I (see Table 5) confirming the fact that the tractor went through distinct load states in the field. The weighted torque $(\mathrm{N} \mathrm{m})$ and power $(\mathrm{kW})$ required to operate the planter in TS-I and TS-II are summarized in Table 5. The tractor in field $1 \mathrm{C}$ consumed the least power in both tractor states as it was not loaded for significant amount of time because of extended non-working periods. Similar to $\mathrm{NH}_{3}$ application and field cultivation,

Table 3. Weighted average torque and weighted average power of 4WD tractor during anhydrous NH3 application and field cultivation in TS-I, TSII and TS-III.

\begin{tabular}{|c|c|c|c|c|c|c|c|c|c|c|}
\hline \multirow[t]{2}{*}{ Field operation } & \multirow[t]{2}{*}{ Field name } & \multicolumn{3}{|c|}{ Weighted average torque $(\mathrm{N} \mathrm{m})$} & \multicolumn{3}{|c|}{ Weighted average engine speed (rpm) } & \multicolumn{3}{|c|}{ Weighted average power $(\mathrm{kW})$} \\
\hline & & TS-I & TS-II & TS-III & TS-I & TS-II & TS-III & TS-I & TS-II & TS-III \\
\hline NH3 application & $3 M S I D$ & 89 & 257 & 580 & 884 & 1711 & 2009 & 8.26 & 45.95 & 121.95 \\
\hline \multirow[t]{3}{*}{ Field cultivation } & $1 C$ & 145 & 368 & 736 & 1455 & 1568 & 1767 & 22.08 & 60.40 & 136.14 \\
\hline & $2 \mathrm{C}$ & 145 & 390 & 758 & 1543 & 1696 & 1964 & 23.42 & 69.30 & 155.91 \\
\hline & $2 \mathrm{D}$ & 145 & 368 & 703 & 905 & 1541 & 1827 & 13.71 & 59.36 & 134.37 \\
\hline
\end{tabular}


Table 4. Weighted average torque and weighted average fuel use rate of MFWD tractor for planting operation in TS-I and TS-II.

\begin{tabular}{|c|c|c|c|c|c|c|c|c|}
\hline \multirow[t]{2}{*}{ Field operation } & \multirow[t]{2}{*}{ Field name } & \multirow{2}{*}{$\begin{array}{l}\text { Avg. ground } \\
\text { speed }\left(\mathrm{km} \mathrm{h}^{-1}\right)\end{array}$} & \multicolumn{2}{|c|}{ Weighted \% torque } & \multicolumn{2}{|c|}{ Weighted fuel rate $\left(\mathrm{L} \mathrm{h}^{-1}\right)$} & \multicolumn{2}{|c|}{$\%$ of total field time } \\
\hline & & & TS-I & TS-II & TS-I & TS-II & TS-I & TS-II \\
\hline \multirow[t]{2}{*}{ Corn Planting } & $1 C$ & 6.14 & 37 & 76 & 10.15 & 24.70 & 41 & 59 \\
\hline & $12 \mathrm{D}$ & 7.83 & 35 & 82 & 11.80 & 27.74 & 2 & 98 \\
\hline
\end{tabular}

Table 5. Variation of load on the MFWD tractor for planting operation in TS-I and TS-II.

\begin{tabular}{|c|c|c|c|c|c|c|c|}
\hline Field operation & Field name & \multicolumn{2}{|c|}{ Weighted engine torque $(\mathrm{N} \mathrm{m})$} & \multicolumn{2}{|c|}{ Weighted engine speed (rpm) } & \multicolumn{2}{|c|}{ Weighted engine power $(\mathrm{kW})$} \\
\hline \multirow[t]{2}{*}{ Corn planting } & $1 C$ & 213 & 438 & 904 & 1514 & 20.19 & 69.44 \\
\hline & $12 \mathrm{D}$ & 202 & 473 & 1492 & 1545 & 31.51 & 76.45 \\
\hline
\end{tabular}

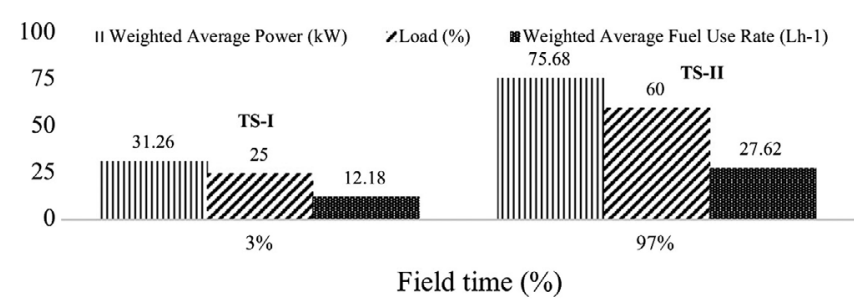

Figure 15. Weighted average power and fuel use rate of the MFWD tractor in TS-I and TS-II for planting operation.

weighted averages of power and fuel use rated were performed across fields $2 \mathrm{D}$ and $12 \mathrm{D}$ based on the percent field time in each tractor state to estimate representative load states for planting operation. Field $1 \mathrm{C}$ was not considered in the weighted average calculation to avoid inaccuracies in the weighted average values (see Table 5). For fields 2D and 12D, the planting operation used approximately $75.68 \mathrm{~kW}$ in TS-II and $31.36 \mathrm{~kW}$ in TS-I, whereas an average fuel use rate of $27.62 \mathrm{~L} \mathrm{~h}^{-1}$ and $12.18 \mathrm{~L} \mathrm{~h}^{-1}$ resulted in TS-II and TSI, respectively (see Figure 15).

Weighted power and fuel use rates in TS-I, TS-II and TS-III were weighted averaged based on the percent field times of each state to determine a composite power and fuel use rates of the $\mathrm{NH}_{3}$ application and the field cultivation operations. A comparison of the power consumed by the implements, load percentages and the fuel use rates of the tractors pulling the $\mathrm{NH}_{3}$ applicator, field cultivator and the planter is presented in Figure 16. It should be noted that the field cultivation and $\mathrm{NH}_{3}$ application were performed by a 4WD tractor with $245 \mathrm{~kW}$ rated power and a MFWD tractor with $127 \mathrm{~kW}$ rated power was used for planting. From comparison it can be seen that the field cultivator had the highest demand on the tractor in terms of power consumed and the fuel use rate. From Figure 16 it can be seen that the average load on the 4WD for $\mathrm{NH}_{3}$ application operating at a ground speed of approximately $7.64 \mathrm{~km} \mathrm{~h}^{-1}$ was found to be $93.74 \mathrm{~kW}$ with a fuel use rate of $42.63 \mathrm{~L} \mathrm{~h}^{-1}$. The 4WD tractor was loaded on an average by $38 \%$ of the rated power during this operation. Also, the tractor was loaded more optimally for planting operation at 59\% engine load compared to $38 \%$ for $\mathrm{NH}_{3}$ application and $48 \%$ for field cultivation indicating that the tractors were oversized in the latter two cases. The power and fuel use rate were divided by the number of rows, 16 in the case of planting operation and number of tools, 13 in the case of $\mathrm{NH}_{3}$ applicator, and 90 for the field cultivator, to yield specific power used by the implements. The specific power and fuel rate values of implements presented in Figure 17 provides a comparison of the load demands of the three field operations. On a per tool basis, $\mathrm{NH}_{3}$ application demanded the highest power of $7.21 \mathrm{~kW} \mathrm{tool}^{-1}$, whereas the field cultivator demanded the lowest $\left(1.31 \mathrm{~kW} \mathrm{tool}^{-1}\right)$. One of the reasons for high power requirement for the $\mathrm{NH}_{3}$ applicator is the working depth of $22 \mathrm{~cm}$ compared to field cultivator which was operated at a depth of $7 \mathrm{~cm}$ (secondary tillage). The specific power requirements and fuel use rates of field cultivation and planting obtained from the CAN data were compared to the specific power requirements and fuel use rates suggested by the ASABE standards (ASABE, 2011a).

No suggestions were made for $\mathrm{NH}_{3}$ application in the ASABE standards and hence specific power requirements obtained in this study for $\mathrm{NH}_{3}$ application were compared to the $\mathrm{NH}_{3}$ application power requirements suggested by Godwin and O'Dogherty (2007).

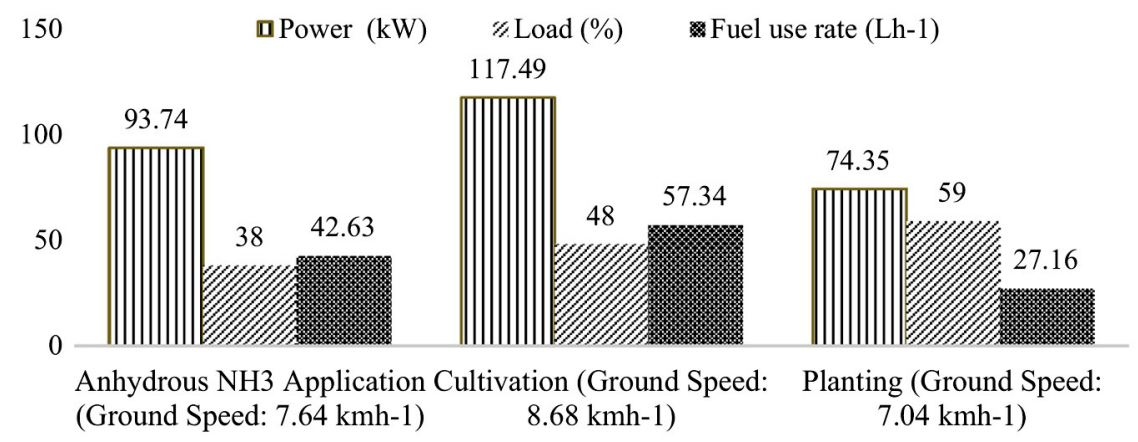

Figure 16. Comparison of weighted average power and fuel use rates of $\mathrm{NH3}$ application, field cultivation and planting operations. 


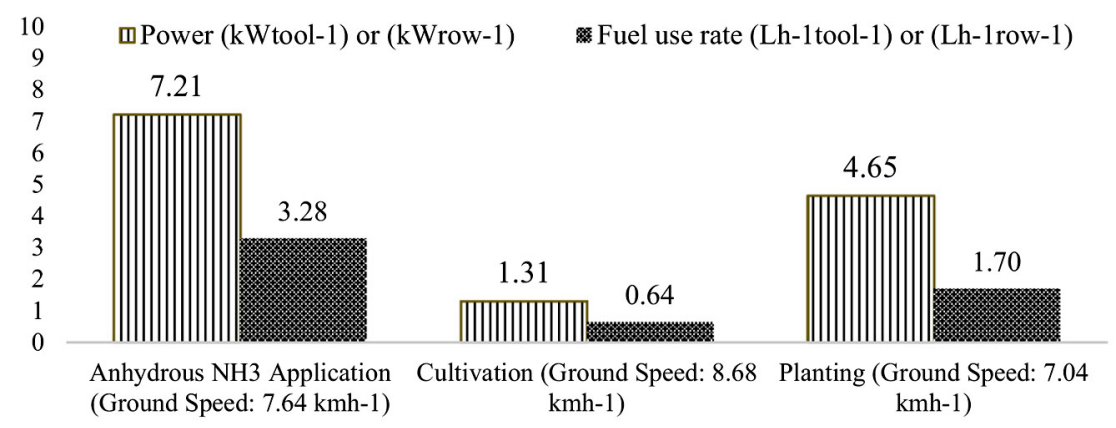

Figure 17. Comparison of power and fuel use rates per row/tool for $\mathrm{NH} 3$ application, field cultivation and planting.

Table 6. CAN specific power and fuel use rate comparison to specific power and fuel use rate values obtained from equations of ASABE standards and other research studies.

\begin{tabular}{|c|c|c|c|c|c|c|}
\hline & \multicolumn{2}{|c|}{ Anhydrous application } & \multicolumn{2}{|c|}{ Field cultivation } & \multicolumn{2}{|c|}{ Corn planting } \\
\hline & CAN data & Godwin \& O'Dogherty (2007) & CAN data & ASABE (2011a) & CAN data & $\overline{\operatorname{ASABE}(2011 a)}$ \\
\hline Specific power (kW tool ${ }^{-1}$ or $k W$ row $\left.^{-1}\right)$ & 7.21 & 5.96 & 1.31 & 1.34 & 4.65 & 4.37 \\
\hline
\end{tabular}

From Table 6 it can be seen that the specific power and specific fuel rate of $\mathrm{NH}_{3}$ application determined from CAN data were slightly over estimated compared to the specific power and fuel rate values suggested by Godwin and O'Dogherty (2007). For cultivation and planting, specific power and fuel rate values obtained from the CAN data were closer to the specific power and fuel rate values suggested by the ASABE standards (2011a), but no particular trend was observed. Extensive data have to be collected from a large sample of tractors and fields to further investigate the comparison of specific power and fuel rate values obtained from machine CAN data to the power requirements of the implements suggested by the ASABE standards and other research studies.

\section{Conclusions}

In-field tractor data was successfully collected from tractors performing $\mathrm{NH}_{3}$ application, field cultivation and planting operations. It was evident from the load and fuel use rate data that multiple tractor load states with different fuel use and load demand magnitudes existed within a given field for the same operation. Based on the fuel use rate and percent torque frequency distributions, $\mathrm{NH}_{3}$ application and field cultivation were found to have three distinct work states: TS-I (idle state), TS-II (working state in turns) and TS-III (working state in parallel and headland passes). Planting operations were divided into two tractor states TS-I (idle state) and TS-II (working state in parallel passes, headland passes and turns) as it was not possible to separate turns from parallel and headland passes in the frequency distribution. Identification of different tractor load states provided an insight into the actual power needs of the implements during working and non-working periods. The 4WD tractor, on average, was loaded $38 \%$ for $\mathrm{NH}_{3}$ application and $48 \%$ for field cultivation indicating that a less rated power tractor model could have been used. $\mathrm{NH}_{3}$ application and field cultivation, on average, required a specific power of 7.21 and $1.31 \mathrm{~kW} \mathrm{tool}^{-1}$, and fuel use rates of 3.28 and $0.64 \mathrm{~L} \mathrm{~h}^{-1}$ tool-1 at $7.64 \mathrm{~km} \mathrm{~h}^{-1}$ and $8.68 \mathrm{~km} \mathrm{~h}^{-1}$ grounds speeds, respectively. The planter was better matched to the tractor when contrasted with the $\mathrm{NH}_{3}$ applicator and field cultivator noting the tractor load of $59 \%$ of the rated power during the planting operation. The planter required an average specific power of $4.65 \mathrm{~kW}$ $\mathrm{h}^{-1}$ row $^{-1}$ and a fuel use rate of $1.70 \mathrm{~L} \mathrm{~h}^{-1}$ row $^{-1}$ at a ground speed of $7.04 \mathrm{~km} \mathrm{~h}^{-1}$. The specific power needs and the fuel use rates determined in this study can be used to update power sizing, and fuel rate estimation procedures of the ASABE machinery management standards. Data corresponding to typical field times at a certain tractor load, power and fuel rate requirements of the implements can be used by manufacturers and producers for estimating actual power and fuel requirements of production operations, and for improving the field and fuel efficiencies of the machinery. Off-road vehicle emission studies will benefit from the actual load state values (power and fuel rate) of the tractors. Further, standardized tractor tests, which currently use steady state test conditions only, could use the tractor load state information presented for developing testing procedures reflecting actual field conditions.

Acknowledgments - The authors would like to thank Nathan Douridas, Chuck Gamble, and Matt Sullivan at the Farm Science Review, The Ohio State University, for their support during in-field CAN data collection from agricultural field operations. Help from students Andrew Klopfenstein, Dustin Wolters, Brittany Schroeder, and Karl Klopfenstein at the Department of Food, Agricultural and Biological Engineering at The Ohio State University is appreciated.

\section{References}

Al-Suhaibani, S.A., Al-Janobi, A., Al-Majhadi, Y.N., 2010. Development and evaluation of tractors and tillage implements instrumentation system. Am. J. Eng. Appl. Sci. 3 (2), 363-371.

ASABE, 2011a. ASAE D497.7 MAR2011 Agricultural Machinery Management Data. ASABE Standards 2011. St. Joseph, MI.

ASABE, 2011b. ASAE EP496.3 FEB2006 Agricultural Machinery Management. ASABE Standards 2011. St. Joseph, MI.

Burgun, C., Lacour, S., Delacroix, A., Descombes, G., Doyen, V., 2013. Computing time and fuel requirements to assess efficiency of a field work from conventional laboratory tests: application to a plowing operation. Agric. Food Sci. 22 (2), 247-261.

Cupera, J., Sedlak, P., 2011. The use of CAN-bus messages of an agricultural tractor for monitoring its operation. Res. Agric. Eng. 57 (4), 117-127. Darr, M., 2012. CAN bus technology enables advanced machinery management. Resour. Mag. 19 (5), 10-11.

Godwin, R.J., O'Dogherty, M.J., 2007. Integrated soil tillage force prediction models. J. Terramech. 44 (1), 3-14. doi:10.1016/j.jterra.2006.01.001 
Harvey, C., 2003. EPA's newest draft nonroad emission inventory model. In: 12th International Emission Inventory Conference "Emission Inventories-Applying New Technologies", San Diego, California. April 28-May 1, 2003.

ISO, 2006. ISO 8178-1 Reciprocating Internal Combustion Engines - Exhaust Emission Measurement - Part 1: Test-bed Measurement of Gaseous and Particulate Exhaust Emissions. ISO: $\mathrm{CH}-1211$ Geneva 20 Switzerland.

Lin, N., 2014. Prediction of Wheeled tractor Fuel Use Rate Distributions from CANbus Data for Agricultural Field Operation. Master's Thesis. The Ohio State University.

Marx, S.E., 2015. Controller Area Network (CAN) Bus J1939 Data Acquisition Methods and Parameter Accuracy Assessment Using Nebraska Tractor Test Laboratory Data (Master's thesis). University of Nebraska-Lincoln, Lincoln, NE.

Marx, S.E., Luck, J.D., Hoy, R.M., Pitla, S.K., Darr, M.J., Blankenship, E., 2015. Validation of machine CAN Bus J1939 fuel rate accuracy using Nebraska Tractor Test Laboratory fuel rate data. Comput. Electron. Agric. 118, 179-185.
OECD, 2012. Standard Code for the Official Testing of Agricultural and Forestry Tractor Performance. OECD. http://www.oecd.org/tad/code/Code\%202\%20 -\%20Final.pdf

Pitla, S.K., Lin, N., Shearer, S.A., Luck, J.D., 2014. Use of controller area network (CAN) data to determine field efficiencies of agricultural machinery. Appl. Eng. Agric. 30 (6), 829-839.

Pitla, S.K., Luck, J.D., Shearer, S.A., Lin, N.N., Schroeder, B.A., Klopfenstein, A.A., 2013 Work and load performance profiles for agricultural field machinery. In: Con ference Agricultural Engineering 13, VDI-Meg, Land-Technik, 29-36 VDIBerichte $\mathrm{Nr}$ 2193-2013.

SAE, 2013. Standard J1939: Serial Control and Communications Heavy Duty Vehicle Network - Top Level Document. http://standards.sae.org/j1939 201308/

Yahya, A., Zohadie, M., Kheiralla, A.F., Giew, S.K., Boon, N.E., 2009. Mapping system for tractor-implement performance. Comput. Electron. Agric. 69, 2-11. 